\title{
The Wadden Sea as a National Park and UNESCO World Heritage Site: Students' Word Associations with These Two Conservation Designations
}

\author{
Till Schmäing *(D) and Norbert Grotjohann
}

Faculty of Biology, Didactics of Biology (Botany/Cell Biology), University of Bielefeld, 33615 Bielefeld, Germany; norbert.grotjohann@uni-bielefeld.de

* Correspondence: till.schmaeing@uni-bielefeld.de

Citation: Schmäing, T.; Grotjohann, N. The Wadden Sea as a National Park and UNESCO World Heritage Site: Students' Word Associations with These Two Conservation Designations. Sustainability 2021, 13, 8006. https://doi.org/10.3390/ su13148006

Academic Editor: Eila Jeronen

Received: 10 June 2021

Accepted: 15 July 2021

Published: 17 July 2021

Publisher's Note: MDPI stays neutral with regard to jurisdictional claims in published maps and institutional affiliations.

Copyright: (c) 2021 by the authors. Licensee MDPI, Basel, Switzerland. This article is an open access article distributed under the terms and conditions of the Creative Commons Attribution (CC BY) license (https:// creativecommons.org/licenses/by/ $4.0 /)$.

\begin{abstract}
The Wadden Sea ecosystem is unique in many respects from a biological perspective. This is one reason why it is protected by national parks in Germany and by its designation as a UNESCO World Heritage Site. In biology didactics, there are only a few studies that focus on the Wadden Sea. This work investigates students' word associations with the two stimulus words "national park" and "UNESCO World Heritage Site". The survey was conducted among students living directly at the Wadden Sea and among students from the inland. The analysis of the identified associations ( $n=8345$ ) was carried out within the framework of a quantitative content analysis to be able to present and discuss the results on a group level. A statistically significant difference was found between the two groups. Overall, results showed that the students made subject-related associations as well as a large number of associations to both stimulus words that could be judged as non-subject-related. In some cases, a connection with the region of residence could be found, but this was not generally the case. Even students' immediate residential proximity to the Wadden Sea is no guarantee that they have knowledge of the two considered protection terms.
\end{abstract}

Keywords: biology education; didactics of biology; education for sustainable development; environmental education; word associations; quantitative content analysis; Wadden Sea; national park; UNESCO World Heritage Site

\section{Introduction}

The Wadden Sea of northeastern Europe is an important ecosystem. It provides food for up to 12 million water birds that rest, molt, or winter there [1]. In addition, this mudflat is the habitat for a total of about 10,000 different species [2] that have managed to adapt to the difficult living conditions influenced by the tides. The Wadden Sea extends from the Danish coast to the entire German coast to the Dutch North Sea coast [3]. It is the longest continuous mudflat area in the entire world. For the protection of this ecosystem, a trilateral cooperation agreement between the countries involved has existed for several decades [4]. On the national level, the idea of protecting the Wadden Sea was implemented just as long ago. In Denmark, areas of the Wadden Sea were declared nature reserves in 1979 [5], while the first areas in the Netherlands were placed under nature protection one year later [6]. The Wadden Sea in Germany was protected when the corresponding areas were declared as national parks. There are three areas protected in this way, namely, the national parks "Schleswig-Holstein Wadden Sea" [(founded in 1985 [7]), "Lower Saxony Wadden [Sea" (1986 [8]), and "Hamburg Wadden Sea" [8(founded in 1990 [9]). In addition, the Wadden Sea of the Netherlands and that of Germany were designated UNESCO World Heritage Sites in 2009 [10] and that of Denmark in 2014 [11].

In biology, there are various studies in different disciplines that have a connection to the Wadden Sea (e.g., ecology [12], molecular biology [13], ornithology [14]). In contrast, the Wadden Sea has hardly been considered in biology didactics - as has already been 
shown in [15]. So far, content on the Wadden Sea has been used to assess teachers' knowledge $[16,17]$ and to compare it with students' knowledge [18], as well as to investigate the systems competence of student teachers [19]. In the Wadden Sea Learning Lab, the focus is not on the Wadden Sea as a learning site. Rather, the focus is on the competence- and practice-oriented training of biology teachers [20-22]. Educational programs have been designed for the Lower Saxony Wadden Sea National Park [23]. One study focused on an intervention at an out-of-school learning site at the Wadden Sea with regard to the systems thinking of secondary school students [24], while other studies evaluated nature centers at national parks and their educational offerings from a biology didactics perspective [25-27]. So far, there has been no explicit consideration of the Wadden Sea as a place of learning. This is true for the didactics of other disciplines: in art didactics, there was a subject-specific thematization [28,29], in geography didactics, a virtual excursion was developed [30,31], and in physics didactics, various educational offerings for out-of-school learning were developed in a research-based manner for the content area North Sea [32,33]. Only in the field of intercultural communication did the Wadden Sea gain significance as a learning site [34]. However, biology and biology-didactic content are not the focus of attention in the current study.

This paper is part of a project that assumes an empirical research perspective of biology didactics at the Wadden Sea, both in in-school and out-of-school settings [35,36]. This study examines the two protection designations of the Wadden Sea, "National Park" and "UNESCO World Heritage Site", by collecting students' word associations with these terms in the context of education for sustainable development and environmental education. Thus, this study belongs to a scientific investigation that has already considered word associations in response to other stimulus words (Wadden Sea, mudflat hiking tour, and tides) from the subject area of the Wadden Sea [15].

\subsection{Definitional Basics}

To assist in understanding the results presented in the course of the work from a professional perspective, a clarification of the terms "national park" and "UNESCO World Heritage Site" is provided below. This is followed by a discussion these two conservation designations from a social science perspective. Utilizing this two-perspective approach ensures that the terms are considered within a broader context.

\subsubsection{The Term "National Park"}

The original idea of preserving special natural landscapes for future generations emerged as early as the beginning of the 19th century. In 1810, the British poet William Wordsworth demanded that the Lake District region be declared a kind of "national property" [37]. The world's first national park was Yellowstone National Park in the United States and was established in 1872 [38]. The World Conservation Union (IUCN) has established an internationally recognized categorization of protected areas and differentiates fundamentally between seven categories. According to this overview, national parks are classified in category II, which is defined as follows [39]:

"Category II protected areas are large natural or near natural areas set aside to protect large-scale ecological processes, along with the complement of species and ecosystems characteristic of the area, which also provide a foundation for environmentally and culturally compatible spiritual, scientific, educational, recreational and visitor opportunities."

Therefore, in a national park, among other aspects, there should be the possibility for tourists to visit the park to a certain extent. One consequence of this is the scientifically proven occurrence of animals becoming accustomed to humans and less shy. This change is called the "national park effect" [40].

The first national park in Germany, the Bavarian Forest National Park, was established in 1970 [41]. As can be seen from the introduction, there are three different national parks for the protection of the Wadden Sea throughout Germany. The "Law on the National Park 'Lower Saxony Wadden Sea'" discusses the basic aims of this national park from a 
legal frame of reference. In addition to discussing how the general protection purpose should be realized, the law also addresses the concept of zoning, prohibitions of activities that have a negative impact, such as construction or trespassing, as well as organizational responsibilities [42]. The zoning concept regulates, among other things, which areas of the national park may and may not be entered by people. In general, the Lower Saxony Wadden Sea National Park pursues ten objectives. The first five relate to the preservation of this unique ecosystem from different perspectives. Additional central objectives include the restoration of disturbed areas, scientific research, the nature-compatible experience of the national park, and associated high-quality educational and public relations work [43].

From a professional point of view, the term "national park" can therefore be associated with the protection or preservation of nature and as having an impact on human behavior in nature.

\subsubsection{The Term "UNESCO World Heritage Site"}

In 1978, the World Heritage Committee nominated the first twelve World Heritage Sites, eight of which were cultural and four of which were natural [44]. Fundamentally, there is a differentiation between the "World Heritage Sites" and the "Natural World Heritage Sites". As a result of their inscription on the World Heritage List, the respective sites may receive support in various forms. These include, for example, support for certain scientific investigations, the provision and/or training of skilled workers, the supply of equipment, or the granting of (interest-free) loans [45].

For inclusion on the World Heritage List, there are different acceptance criteria for both World Cultural Heritage Sites and Natural World Heritage Sites. With regard to the prerequisites for recognition as a Natural World Heritage Site, a differentiation is made between four basic criteria, which follow those for World Heritage Sites (i.-vi.). In summary, the criteria relate to a superior natural phenomenon to be represented (vii.), geological importance (viii.), representation of important ecological and biological processes (ix.), and relevance to the conservation of biological diversity on Earth (x.) [46]. The Wadden Sea was designated a World Heritage Site since it met the three criteria, viii.-x. [10,11], thereby receiving special international recognition. Being listed on the World Heritage List is not automatically accompanied by an increased legal protection status [47], as this must be implemented at the state level in each case. In Germany, with reference to the Wadden Sea, this is accomplished by the three national parks with their associated legal regulations, as discussed earlier. The World Heritage status can be withdrawn from the respective site due to multiple threats (such as poaching, deforestation, tourism, urbanization, wars, or natural disasters), but prior to this, the site is listed on the World Heritage in Danger List [45].

From a professional perspective, the term "UNESCO World Heritage Site" has a variety of associations that have already been made in the context of the term "national park". Ultimately, the objectives of this international protection status are comparable to those of a national park but are considered on a higher level and are less concrete due to the lack of legal implementation in the respective countries.

\subsection{Social Scientific Consideration of the Conservation Designations}

The two conservation designations presented relate primarily to the protection of nature from a biological or ecological perspective. In addition, ways of thinking and patterns of action in terms of sustainability are of special relevance. It makes sense to refer to the sociological dimension of sustainability since this is linked to the ecological one and therefore acquires a special significance [48].

In sociology, there are different historical approaches for grasping the relationship between nature and sociology or the importance of nature in sociology. A detailed account can be found in [49], in which the author states that since the 1970s, nature has prompted a reorientation of the entire field of sociology as well as associated subject areas due to ecological crises and the challenges they pose, after having been largely ignored previously. As a result of these developments, sociologist Ulrich Beck illustrates the relationship between 
nature and society as follows: "At the end of the 20th century, it is true that nature is society, society is (also) 'nature'. Whoever still speaks of nature as non-society today is talking in the categories of another century, which no longer grasp our reality" [50]. These explanations suggest that the natural environment is almost completely influenced by humans and is therefore no longer untouched [51]. As early as 1986, the socio-cyberneticist Niklas Luhmann also addressed the importance of ecological communication in modern society for ecologically relevant problem areas [52]. At present, environmental sociology plays a central role for the whole field, although there are still different definitional views [53].

Furthermore, there is a broad scientific discourse in sociology about what we humans conceive of as nature in the first place. From a sociological point of view, nature is regarded as a social construct [54]. Our conceptions of nature are therefore culturally determined to a certain degree [55]. Thus, "nature" did not even exist before the invention of this word; the phenomena that are attributed to nature already existed, of course, but people were not aware of them [56]. Another starting point for a concretization of the conceptual consideration can be offered by a definitional differentiation. A distinction has to be made between the understanding of the social construction of nature and its impact on the construction of our concepts of nature and the construction of nature in the physical and material sense [57].

This relationship between nature and society, presented on a meta-level, can be linked to the previous professional descriptions of the national park and the UNESCO World Heritage Site. For example, global sociology offers many points of connection for research in this area because the growing importance of the World Heritage movement is rooted in fundamental processes of globalization [58]. In the case of cultural World Heritage sites, for example, the process required for nomination could be judged as a particular form of social determination of what is valuable [59]. A positive correlation between the designation as a World Heritage Site and the number of tourists at these sites was found with a higher correlation for natural World Heritage Sites (such as the Wadden Sea) than for cultural World Heritage Sites [60]. The places where the World Heritage Sites are located also become more important for international tourism [61]. Therefore, this protective designation has a special relevance, which must be considered from mixed perspectives. For example, the system for designating World Heritage sites is hardly compatible with the ideas of indigenous communities [62], and there is a risk of marginalizing individual groups [63]. However, it is possible that the nomination of a World Heritage Site and the resulting positive impact on economic structures can strengthen social harmony [64].

In terms of the benefits of designation conferral for strengthening sustainability, the conclusion is mixed. Although management plans are intended to mitigate the impacts of tourism and preserve the significance of the sites [65], from an ecological point of view, there are negative impacts that must be mentioned in addition to the social aspects cited. These include the empirically established connection between human activities and forest dieback at UNESCO World Natural Heritage sites [66]. Another form of threat does not come directly from humans but has its origins in the elementary effects of climate change [67]. In the following discussion, Luhmann's considerations about the importance of ecological communication and its relevance to ecological challenges in modern society will be addressed.

\section{Methods}

For the survey, a word association method was selected for the two terms "national park" and "UNESCO World Heritage Site". With this approach, the qualitative demand for openness can be considered, while at the same time the quantitative aspect of a big sample size can be guaranteed. In the following, after a short general description of word association methods, the concrete evaluation methodology that was applied in this study is presented and its selection is justified. This is based on the explanations in [15]. 


\subsection{Word Association Method}

Initial theoretical references to word association procedures can be found as early as in the writings of Aristotle [68]. Corresponding methodological approaches have been used in science for many decades. They are mainly used in psychology, but they are also present in the field of biology didactics [69]. Among other uses, they are recommended as a method for recording learners' cognitive structures [70]. In a practical school context, they can be used either for evaluation [71] or for planning lessons [72]. In addition, there are studies that have investigated the word associations of teachers [73] and student teachers [74-78]. In biology education, out-of-school learning has been empirically investigated with the use of word association procedures $[79,80]$. Other studies have been directed toward eliciting word associations with thematically diverse concepts (e.g., [81-84]).

In general, word association methods are used to determine study participants' associations with a specific stimulus word. From the literature, there are four basic procedures that should be mentioned with regard to the concrete implementation of word association methods. These will be discussed briefly according to Woodworth and Schlosberg [85]. They distinguish two poles, one between continuous and discrete associations as well as another between controlled and free associations. A combination of these poles results in a total of four methodological procedures. In the case of continuous-free associations, any number of associations can be named and there are no restrictions placed on them. In the continuous-controlled association, for example, there are no restrictions on the content of the association. In the case of a single-controlled association method, there is an additional limitation that only a single association word may be named. The single-continuous association takes this single-word limitation into account, but there are no restrictions on the word to be associated.

For the present study, the continuous-free word association method was chosen. With this method, it is possible to guarantee a maximum degree of openness in many respects due to the absence of quantitative or other restrictions. Thus, any number of associations can be named, which are also not restricted on any content level. However, the literature indicates that the selection of the stimulus word is automatically accompanied by an indirect content restriction for the associations. For this reason, the methodology used can also be described as "quasi-free" [86].

\subsection{Analysis Methodology}

Just as there is a variety of possible word association methods that can be selected, there are also many possible evaluation methods. In general, all associations were considered in the evaluation of the data in this study, and no pre-selection was made, so that associations that were unrelated to the content or to the subject were also included in the evaluation. It is essential that these unrelated associations be considered to reduce any bias in the recording of the word associations. Schaefer [87] emphasizes that non-subject associations are not uncommon.

A common analysis method is the measurement of the frequency of the "primary response", namely, the most frequently mentioned associations with a stimulus word [88]. In the present study, the primary response receives extensive consideration, and other associations are also included in the evaluation. A quantitative content analysis was conducted for quantification. For this purpose, a category system was inductively developed from the data material [89]. However, the aim for the category formation was by no means to develop a superordinate system, as was done in comparable studies [90]. Rather, the formation of the categories was oriented towards a level that grasps the associations as literally as possible, so that a very close-meshed system was created. The categories that emerged can not only be described as summarizing the associations, but they are also generally a literal representation of them.

Theoretically, it would have been possible alternatively to look at the data not at the level of the group but to evaluate them at an individual level and, for example, to create chains of associations [81]. Due to the size of the sample and considering the general 
objectives, this analysis method was judged to be neither practicable nor purposeful for the present study, which is why this procedure was not employed.

\section{Research Questions}

The two central research questions can be formulated from the content-related and methodological explanations presented above.

Research Question 1 (RQ1). What word associations do students have with the term "national park"?

Research Question 2 (RQ2). What word associations do students have with the term "UNESCO World Heritage Site"?

An extension of these two questions becomes possible with the realization of the research design: students from North Rhine-Westphalia (inland sample) and students living directly at the Wadden Sea (coast sample) were surveyed. In relation to the immediate proximity to the UNESCO World Heritage Site and the National Park, the following research question is therefore also a focus of the investigation:

Research Question 3 (RQ3). To what extent do the associations of the students from the two regions differ?

\section{Results}

In the following, the results of the quantitative content analysis are illustrated with an increase in tabular overviews (rankings). The survey was conducted among 1675 students living at the Wadden Sea and among 1444 students from North Rhine-Westphalia. Thus, in the illustrations, a differentiation is made between the coast sample (50.57\% male, average age: 13.40 years) and the inland sample (50.48\% male, average age: 13.59 years). The students who were surveyed attended different school types representing different academic levels. The survey was conducted not only among university-track high school students ("Gymnasium") but also among students from other school types. In order to ensure comparability between the two groups, the study was designed and conducted to ensure a similar distribution of students from the respective school types. In total, the students made 8345 associations in response to the two stimulus words "national park" and "UNESCO World Heritage Site", which were analyzed in the quantitative content analysis.

A key measure for ensuring objectivity is interrater reliability. For this purpose, Cohen's kappa is presented as a useful measure in the didactics of natural sciences [91]. For implementations, $10 \%$ of the data were coded independently by two individuals. The set of data was selected with reference to methodological literature [92] and in line with other biology didactic studies [93]. The determined k-value was 0.971. According to Altman [94], this value is excellent.

To compare the students of both samples, a $\chi^{2}$-test was performed. This was suitable because the data under consideration were nominally scaled. The $\chi^{2}$-test involves a comparison of the obtained data with those from an expected distribution [95]. This statistical procedure was implemented for both stimulus words. Since the expected cell frequency was less than five in some cases, a Monte Carlo simulation was performed for each. As can be seen from the results section, the differences between both groups with respect to both stimulus words are statistically significant. To describe this effect more precisely, Cramér's V was calculated in each case [96].

Paying particular attention to the third research question, two rankings are presented for each stimulus word. These represent the categories formed from the associations of the two samples in a separate presentation form. In addition, the absolute numbers of the associations mentioned as well as the associations per student can be seen in the headings of the tables.

Tables 1 and 2 illustrate the most frequently mentioned associations with the stimulus word "national park". The $\chi^{2}$-test determined that the difference between the two groups 
was statistically significant $\left(\chi^{2}(135)=720.112, p<0.001\right)$. Cramér's V was 0.376 , so it was a moderately strong effect [97].

Table 1. Stimulus word: national park; sample: coast; associations $n=2614$; associations/individual: 1.56 .

\begin{tabular}{cccc}
\hline Item & Association & $\mathbf{n}$ & $\mathbf{\%}$ \\
\hline 1 & Nature conservation & 415 & 15.88 \\
2 & Animals & 311 & 11.90 \\
3 & Amusement park & 196 & 7.50 \\
4 & City park & 137 & 5.24 \\
5 & Nature & 104 & 3.98 \\
6 & Wadden Sea & 97 & 3.71 \\
7 & Place with special rules for people & 96 & 3.67 \\
8 & Tree/forest & 95 & 3.63 \\
9 & Joy/pleasure & 70 & 2.68 \\
9 & Birds & 70 & 2.68 \\
11 & Plants & 64 & 2.45 \\
12 & Term is unknown & 58 & 2.22 \\
13 & For humans & 53 & 2.03 \\
14 & Generally positive description & 46 & 1.76 \\
15 & Information possibility/knowledge transfer & 43 & 1.64 \\
\hline
\end{tabular}

Table 2. Stimulus word: national park; sample: inland; associations $n=2745$; associations/individual: 1.90 .

\begin{tabular}{cccc}
\hline Item & Association & $\mathbf{n}$ & $\mathbf{\%}$ \\
\hline 1 & Nature conservation & 399 & 14.54 \\
2 & Animals & 331 & 12.06 \\
3 & City park & 299 & 10.89 \\
4 & Amusement park & 238 & 8.67 \\
5 & Tree/forest & 173 & 6.30 \\
6 & Nature & 172 & 6.27 \\
7 & Zoo & 112 & 4.08 \\
8 & Reference to the USA & 97 & 3.53 \\
9 & Plants & 82 & 2.99 \\
10 & National & 81 & 2.95 \\
11 & Place with special rules for people & 62 & 2.26 \\
12 & For people & 59 & 2.15 \\
13 & International & 50 & 1.82 \\
14 & Meadow/grass & 46 & 1.68 \\
15 & Term is unknown & 45 & 1.64 \\
\hline
\end{tabular}

Tables 3 and 4 illustrate the most frequently mentioned associations with the stimulus word "UNESCO World Heritage Site". A statistically significant difference between the two groups considered was also found with regard to this stimulus word $\left(\chi^{2}(138)=450.783, p<0.001\right)$. The effect size according to Cramér's V was 0.389 and therefore equally moderate [97].

Table 3. Stimulus word: UNESCO World Heritage Site; sample: coast; associations $\mathrm{n}=1478$; associations/individual: 0.70 .

\begin{tabular}{cccc}
\hline Item & Association & $\mathbf{n}$ & $\mathbf{\%}$ \\
\hline 1 & Nature conservation & 308 & 20.84 \\
2 & Term is unknown & 215 & 14.55 \\
3 & Wadden Sea & 148 & 10.01 \\
4 & Unique/special & 100 & 6.77 \\
5 & Nature & 80 & 5.41 \\
6 & Organization & 41 & 2.77 \\
7 & Animals & 39 & 2.64 \\
\hline
\end{tabular}


Table 3. Cont.

\begin{tabular}{cccc}
\hline Item & Association & $\mathbf{n}$ & $\mathbf{\%}$ \\
\hline 8 & Heritage & 32 & 2.17 \\
9 & General positive description & 31 & 2.10 \\
10 & Concerning the world & 30 & 2.03 \\
11 & Tree/forest & 25 & 1.69 \\
12 & Relevance & 23 & 1.56 \\
12 & Place with special rules for people & 23 & 1.56 \\
14 & Historical dimension & 22 & 1.49 \\
15 & Plants & 18 & 1.22 \\
\hline
\end{tabular}

Table 4. Stimulus word: UNESCO World Heritage Site; sample: inland; associations n = 1508; associations/individual: 1.04 .

\begin{tabular}{cccc}
\hline Item & Association & $\mathbf{n}$ & \% \\
\hline 1 & Nature conservation & 346 & 22.94 \\
2 & Term is unknown & 14.46 \\
3 & Relation to other World Heritage Site & 137 & 9.08 \\
4 & Unique/special & 101 & 6.70 \\
5 & Nature & 91 & 6.03 \\
6 & Organization & 69 & 4.58 \\
7 & Relevance & 49 & 3.25 \\
8 & Wadden Sea & 47 & 3.12 \\
9 & Science & 46 & 3.05 \\
11 & Concerning the world & 44 & 2.92 \\
12 & Heritage & 43 & 2.85 \\
13 & Place with special rules for people & 39 & 2.59 \\
15 & Historical dimension & 27 & 1.79 \\
\hline
\end{tabular}

\section{Discussion}

The results presented are discussed below with regard to the two stimulus words under various aspects. This includes both a general discussion of the associations and the categories formed from them (RQ 1 and 2) as well as a comparison of the results from the two samples (RQ 3). After the naming of a certain category, the percentage of the associations along with the total number of associations with the respective stimulus word in the corresponding sample is given immediately in brackets. The first indication refers to the coast sample, the second to the inland sample. If there is only one indication, the corresponding category is only present in one ranking. The naming of the categories is done in quotation marks in order to emphasize them and also to relate the literal dimension to the associations.

\subsection{Stimulus Word "National Park"}

The results for the stimulus word "national park" are discussed not only within the context of comparing the two samples with each other but also within a meaningful context with existing findings from other studies. However, these studies do not have a direct biology didactics background but are mainly oriented towards the field of tourism research or geography. Association experiments related to the term national park were mostly conducted through surveys of visitors to a national park or only made a distinction between local and non-local persons. Association methods are used in these disciplines to investigate the acceptance of nature reserves or national parks [98-100]. Although children were often surveyed in these studies, they generally made up a low proportion of the respective samples or were not considered separately. The results of the present study cannot be directly compared with those from other studies. In addition, so far, no word association study on the term "national park" has been conducted with reference to the Wadden Sea 
National Park. Since other national parks have received partial consideration in the surveys, any related associations are influenced by these other parks. Nonetheless, in some areas, the results may provide insight into the general meaning of certain associations with the term "national park" and will be taken up in appropriate places within the discussion.

Both the students of the coastal sample and the inland sample associate the stimulus word "national park" with words belonging to the category "nature conservation" $(15.88 \% / 14.54 \%)$. This indicates that a large number of students associate a central objective with a national park, regardless of their residential proximity to it. A study on the Eifel National Park showed that tourists see nature conservation as the primary goal of a national park [101]. In second place, the category "animals" $(11.90 \% / 12.06 \%)$, was also be found in both rankings. This indicates that such associations are of great importance in both samples. In studies on the Swiss National Park [102] and the Bavarian Forest National Park [103], this content field was also shown to be relevant in relation to visitors' conceptions.

In third place and fourth place, the two rankings included the categories "amusement park" (7.50\%/ $8.67 \%)$ and "city park" (5.24\%/10.89\%). Both were constructed from associations that, from a subject-related perspective, do not immediately suggest the term national park. In particular, the associations from the category "amusement park" usually do not have a direct subject-related connection to the national park. This is because the park is associated with an amusement park, with its various attractions, such as rides or snack stands. This result was completely independent of the students' place of residence. The occurrence of associations, which can be assigned to a corresponding category, could be connected with a literal derivation. Nevertheless, the frequent mentioning of these associations - especially by students living directly at the Wadden Sea National Park-is astonishing, if not even alarming. The same picture emerged for the category "city park". Due to the general objectives and the associated regulations for people, a national park can even be seen as the opposite of a city park, which is primarily aimed at providing recreational opportunities for people. A national park also offers this in some areas considering the zoning concept, but untouched nature is the central focus. All the more remarkable at this point is the frequent naming of related associations which occurred with significant frequency in both samples. This impression is supported by the category "for people" $(2.03 \% / 2.15 \%)$, which was also found in both rankings. In light of the above explanations, this category in particular describes an opposite view of the national park. Here, too, having a place of residence at the Wadden Sea had no influence on the associations. This was followed by the category "zoo" $(4.08 \%)$, which was only relevant in the inland sample. In this context, the relevance of the category "term is unknown" $(2.22 \% / 1.64 \%)$ can be discussed in addition to the misconception of content. The fact that more than every hundredth association from the coast sample students illustrates unfamiliarity with the term is especially surprising due to the associated place of residence and the immediate proximity to the Wadden Sea.

However, the students in both samples also named numerous associations that have a clear connection to the national park. These include, among others, those that were assigned to the category "nature" (3.98\%/6.27\%). A study on the Bavarian Forest proved the importance of these associations [104]. Those from the categories "tree/forest" (3.63\%/6.30\%) and "plants" $(2.45 \% / 2.99 \%)$ can be considered to belong the "nature" category as well. It is not surprising that the students of the coast sample directly referred to the "Wadden Sea" $(3.71 \%)$. This was not the case for the students of the inland sample, although the data were collected before a content-related reference to the Wadden Sea. Thus, the surveyed students living in inland areas did not seem to be directly aware that the Wadden Sea in Germany is protected by three national parks.

The category "place with special rules for people" (3.67\%/2.26\%), which again can be taken from both rankings, is also striking. Associations from this category illustrate the restrictions on human actions in the national park that are necessary to achieve the goals and can be confirmed from a content-related perspective. All in all, a very heterogeneous picture seems to emerge, which can be substantiated with both professional and nonprofessional 
associations. The fact that the category "joy/pleasure" (2.68\%) was only found in the ranking of the coast sample could be an indication of the students' experiences at the national park. This would again be supported by the local proximity to the Wadden Sea. The category "general positive description" $(1.76 \%)$, which was also only in the ranking of the coast sample, supports this conclusion. However, in a study on the Eifel National Park, children were shown to have a general positive evaluation of the National Park [105]. Since the importance of the category "information possibility/knowledge transfer" $(1.65 \%)$ was also only found in the ranking of the coast sample, corresponding associations could refer to the students' own learning processes that were already carried out in the mud flats. In contrast, the categories "national" $(2.95 \%)$ and "internationality" $(1.82 \%)$ were found in the ranking of the inland sample. These associations can again be traced with a literal derivation from the stimulus word "national park" and thus are not related to content. In contrast, the category "reference to the USA" $(3.53 \%)$ can be technically understood in reference to the historical development of national parks.

A particular diversity of associations emerges from the presentations. Even if the multitude of non-subject-related or technically incorrect associations may be surprising at first glance, additional literature relativizes this impression. For example, Groß [26] investigated educational institutions at the Lower Saxony Wadden Sea National Park and interviewed visitors of different age groups about their perceptions of the national park after visiting the exhibitions. From the 109 interviews, it could be seen that even after people visited the facilities, hardly any scientific concepts about the national park prevailed. Furthermore, the present study was able to confirm the finding from Groß's study that there is a connotation of the term national park with a (city) park and often a connection is made with "the national level" / "of a nation". In this context, Groß mentions the commonalities of the ideas in different age groups as well as the connotation being independent of educational qualifications.

\subsection{Stimulus Word "UNESCO World Heritage Site"}

As with the term "national park", there are also various methodological and contentrelated approximations for the designation "UNESCO World Heritage Site", especially in tourism research. There are studies available that have considered both World Natural and World Cultural Heritage sites in conceptual terms. Ultimately, these studies primarily examined the attitudes of (potential) visitors to various World Heritage sites in order to draw conclusions about tourist attractions or explanations for tourist behavior. Likewise, the impact of designating a site with the term "World Heritage" is often discussed in the literature. Among other methods, word association methods have been used (for a review of selected results, see [106]). From a biology didactics perspective, the findings of these studies are largely irrelevant to the questions addressed in this paper. Moreover, they mostly relate to Cultural World Heritage Sites. Once again, higher-level references are illustrated only at selected points in the discussions, but they can in no way be considered another standard for comparison.

In the respective rankings of the categories for the term "national park" and the stimulus word "UNESCO World Heritage Site", there was some overlap with regard to the associations present in both. For the two stimulus words, the associations most frequently named by the students of both samples were those that can be assigned to the category "nature conservation" $(20.84 \% / 22.91 \%)$. These associations are understandable from a technical point of view, as they illustrate the relevance or the general objective of this award. In second place in both rankings was the category "term is unknown" $(14.55 \% / 14.46 \%)$. Therefore, it can be assumed that the term "UNESCO World Heritage Site" is clearly more unknown than that of "National Park". It can be considered surprising that so many students who live directly at the UNESCO World Heritage Site Wadden Sea describe this term with their associations as unknown. Students' local proximity to a World Heritage Site does not directly indicate that the students are knowledgeable about this term. This general result was further confirmed by looking at the number of associations per student: 
1.72 for the stimulus word "national park" and an average of only 0.96 associations for "UNESCO World Heritage Site".

The category "Wadden Sea" (10.01\%/3.12\%) was in third place in the ranking, which resulted from the formation of categories from the coast sample students' associations. Similar to what was stated before, this stimulus word also had a special reference to the Wadden Sea, which is located in the immediate vicinity. In contrast to the term "national park", the surveyed students from the inland also mentioned associations with the term, "Wadden Sea", and this can be explained by the consideration of the general data collection on the context of the Wadden Sea. In the ranking of this sample, the category "reference to other World Heritage Site" (9.08\%) took the third place. This category mainly included associations that refer to the Zollverein colliery (coal mine) and also to a World Heritage Site from the immediate vicinity of the surveyed students. Therefore, clear parallels can be drawn with the category "Wadden Sea", which is comparably important in the coast sample.

The students from both samples mentioned associations of the category "unique/special" $(6.77 \% / 6.70 \%)$ comparably often. This characterization of World Heritage Sites is reasonable from a technical viewpoint and is also in line with other study results which refer particularly to World Heritage Sites $[106,107]$. Following this, there was the category "relevance" $(1.56 \% / 3.25 \%)$. The associations from this illustrate the necessity of preserving World Heritage sites.

With the category "nature" (5.41\%/6.03\%), a reference to the Wadden Sea was evident as well as a literal derivation from the stimulus word. The latter also applies to the categories "heritage" $(2.17 \% / 2.85 \%)$ and "concerning the world" $(2.03 \% / 2.92 \%)$. The categories were found in both rankings. With the focus on the subject-related understanding of these associations, the category "animals" $(2.64 \% / 1.59 \%)$ should also be mentioned which also occurred in both rankings. In contrast, associations pertaining to the categories "tree/forest" (1.69\%) and "plants" (1.22\%) were only mentioned to a considerable extent by the students from the coast sample. A starting point for an explanation, at least for the associations of the second category, could be the occurrence of plants in the Wadden Sea or in the adjacent salt marshes.

Word associations which are attributed to the term "UNESCO World Heritage Site" in the course of definitional development that can be included under the category "organization" $(2.77 \% / 4.58 \%)$ had a non-negligible importance in both samples. From a technical point of view, the reference here is to UNESCO as an organization rather than to a specific World Heritage Site. As in the other studies consulted [108], which refer particularly to cultural World Heritage sites instead of natural ones, the associations from the category "historical dimension" (1.49\%/1.79\%) were also relevant in this study. Due to the reference to a natural World Heritage Site, this result could be an indication of a lack of differentiation between natural World Heritage Sites and cultural World Heritage Sites.

Clear references to the Wadden Sea can be inferred indirectly via the associations from the category "national park" $(1.13 \%)$, which were mainly expressed by the students of the inland sample. In this area, the two stimulus words could be seen to overlap in terms of their associations. This is logical due to the generally comparable objectives. A further indication of this is the category "place with special rules for people" $(1.56 \% / 2.59 \%)$, which was again found in both rankings. Associations that characterize this category also appeared in considerable numbers for the other stimulus word, as already discussed. Therefore, this comparison of the two protection designations made with the corresponding associations can be illustrated. From a technical point of view, it should be noted that the designation as a UNESCO World Heritage Site does not entail any legal consequences. Through the laws in force in the national park, legal consequences can be established, but this has in no way a direct relation to the UNESCO World Natural Heritage.

The category "general positive description" $(2.10 \%)$ was found exclusively in the ranking of the coast sample. This result confirms the assumption already made with regard to the stimulus word "national park" that personal experiences with the Wadden Sea play 
a special role in the associations. Associations that can be assigned to the category "science" $(3.05 \%)$, on the other hand, only occurred in the ranking from the inland sample. From a technical point of view, statements in this category make sense, especially with reference to funding possibilities for World Heritage Sites.

\section{Conclusions}

In the present study, students' word associations to the two terms "national park" and "UNESCO World Heritage Site" were determined, and the relevance of subject-related as well as non-subject-related associations could be shown. Some starting points for further research projects could include clarifying the numerous non-subject-related associations (especially to the stimulus word "national park") as well as identifying further associations.

In addition, projects that focus on the sociological dimension of sustainability are also useful and could be linked to the theoretical explanations given in Section 1.2. For example, it would be possible in a subsequent study to consider the sociological meaning of sustainability in relation to the two conservation designations for the specific case of the Wadden Sea ecosystem. For this purpose, interviews could be conducted to record the students' ideas in detail and refer back to the results of this study. In light of the sociological discourse regarding the definition of nature as a social construct, further research could be conducted with other stakeholders. A survey of staff members from different areas of the national park could provide insight into any commonly held conception of the relationship between nature and society with reference to Beck's theoretical anchors. Within the framework of the present project, the employees from the educational institutions on the Wadden Sea seem particularly suited for exploring this relationship from their particular perspective. It would also be possible, among other things, to study the compromises between social, economic, and ecological areas of interest regarding the Wadden Sea in terms of their pedagogical presentation to the various student groups.

Furthermore, teachers and also learners could be asked about concrete threats to the Wadden Sea and how to deal with them, in reference to Luhmann's description of challenges for modern society regarding ecological problems. The Wadden Sea is exposed to many different threats. For example, oil is extracted in the national park [108], and the effects of climate change-often in combination with overfishing-also have far-reaching impacts on the species composition in the ecosystem [109]. From the interdisciplinary perspective of sustainability, the consequences of mass tourism also resulting from the designation as a national park and UNESCO World Heritage Site are of particular interest. In this area, in addition to positive effects, for example with regard to educational work, there are also projects that contradict a national park-friendly tourism development [110]. In corresponding studies, references to the Wadden Sea as a UNESCO World Heritage Site and as a national park could again be made. For example, studies could examine the various stakeholders as they are confronted with the empirically determined mixed consequences of the protection designations. Existing studies have used different methodological approaches to investigate the acceptance of the Lower Saxony Wadden Sea National Park among the local population [111].

From a biology didactic perspective, the Wadden Sea is not only a place of learning and a subject of lessons for students but also offers adults the opportunity of (informal) learning. Therefore, it is in the interest of tourist research to conduct studies with adults and families. Again, a consideration of the two protection designations is especially important as it can be linked to the studies presented in the theoretical part of this paper. The presented results do not refer specifically to the Wadden Sea but instead generally reflect overall trends in relation to UNESCO World Heritage Sites and national parks. It seems reasonable to empirically investigate the effects of the designation of the Wadden Sea as a National Park and, due to the number of available studies in the literature, specifically as a UNESCO World Heritage Site. Similar studies have already been conducted on the socio-economic monitoring of the Schleswig-Holstein Wadden Sea National Park. Among other things, the awareness of the Wadden Sea's designation as a UNESCO World Heritage Site was 
investigated. This distinction was found to be largely unknown, even among the local population [112].

For more specific details regarding how the in-depth studies with a biological focus could be conceived and conducted, see [15]. Likewise, it is possible to repeat the survey with a different sample and explore whether local proximity to another national park has a different influence than reported in this study.

In summary, the results obtained in this study provided additional in-depth insight into the learner perspective on the Wadden Sea in relation to the two stimulus words. Nonetheless, there are still no biology didactic studies focusing on the Wadden Sea as a learning site. In addition to the conceptual cues discussed for studies with a particular sociological focus, studies with a focus on constructs particularly relevant to biology education can also be implemented. The results obtained provide support for the design and general understanding of such studies. For example, it is possible to take the positive descriptions and enjoyment/pleasure related to the National Park highlighted in the relevant categories in this study as a reason to look at the experience of nature at the Wadden Sea. It is also possible to investigate the influence of activities at the Wadden Sea on the students' interest or motivation. In the same way, taking the associations with the categories animals and plants into account would not only allow experience-oriented research to be done but would also make it possible to determine the students' specific knowledge of species. The category information transfer/knowledge transfer attributes such a task to the National Park-also in specific reference to the Wadden Sea National Park.

Therefore, in summary, there are numerous starting points for further biology didactics research on the unique ecosystem of the Wadden Sea. The results of the present study provide an important basis for the conception of these future studies, which could focus on education for sustainable development.

Author Contributions: Conceptualization, T.S.; data curation, T.S.; formal analysis, T.S.; funding acquisition, T.S.; investigation, T.S.; methodology, T.S.; project administration, T.S.; resources, T.S.; software, T.S.; supervision, N.G.; validation, N.G.; visualization, T.S.; writing-original draft, T.S.; writing-review and editing, N.G. All authors have read and agreed to the published version of the manuscript.

Funding: We acknowledge support for the publication costs by the Open Access Publication Fund of Bielefeld University.

Institutional Review Board Statement: Not suitable.

Informed Consent Statement: Not suitable.

Data Availability Statement: The data presented in this study are available on request from the corresponding author. The data are not publicly available due to privacy.

Conflicts of Interest: The authors declare no conflict of interest.

\section{References}

1. $\quad$ Laursen, K.; Blew, J.; Eskildsen, K.; Günther, K.; Hälterlein, B.; Kleefstra, R.; Lüerßen, G.; Potel, P.; Schrader, S. Migratory Waterbirds in the Wadden Sea 1987-2008: Trend, Phenology, Distribution and Climate Aspects. Wadden Sea Ecosystem No. 30; Common Wadden Sea Secretariat, Joint Monitoring Group of Migratory Birds in the Wadden Sea: Wilhelmshaven, Germany, 2010.

2. Hofstede, J.L.A.; Stock, M. Climate change adaptation in the Schleswig-Holstein sector of the Wadden Sea: An integrated state governmental strategy. J. Coast Conserv. 2018, 22, 199-207. [CrossRef]

3. Dijkema, K.S. Towards a habitat map of the Netherlands, German and Danish Wadden Sea. Ocean. Shorel. Manag. 1991, 16, 1-21. [CrossRef]

4. Enemark, J.A. Die deutsch-dänisch-niederländische Zusammenarbeit zum Schutz des Wattenmeeres. Ein Beispiel für den internationalen Naturschutz. In Internationaler Naturschutz; Erdmann, K.-H., Ed.; Springer: Berlin/Heidelberg, Germany, 1997; pp. 177-190; ISBN 978-3-642-64514-3.

5. Laursen, K.; Frikke, J. Hunting from motorboats displaces Wadden Sea eiders Somateria mollissima from their favoured feeding distribution. Wildl. Biol. 2008, 14, 423-433. [CrossRef]

6. Nehring, S.; Hesse, K.-J. Invasive alien plants in marine protected areas: The Spartina anglica affair in the European Wadden Sea. Biol. Invasions 2008, 10, 937-950. [CrossRef] 
7. Goeldner, L. The German Wadden Sea coast: Reclamation and environmental protection. J. Coast Conserv. 1999, 5, 23-30. [CrossRef]

8. Südbeck, P.; Rahmel, J. The Lower Saxon UNESCO Biosphere Reserve Programme. In Waddenland Outstanding; Egberts, L., Schroor, M., Eds.; Amsterdam University Press: Materdam, The Netherlands, 2018; pp. 283-292; ISBN 9789048537884.

9. Körber, P. Biosphärenreservat Hamburgisches Wattenmeer. In Biosphärenreservate in Deutschland; Ständige Arbeitsgruppe der Biosphärenreservate in Deutschland, Ed.; Springer: Berlin/Heidelberg, Germany, 1995; pp. 121-125; ISBN 978-3-642-63367-6.

10. UNESCO. REPORT OF DECISIONS: Extract of the Report Agenda Item 8B-Nominations to the World Heritage List Decision 33 COM 8B.4; UNESCO: Seville, Spain, 2009.

11. UNESCO. Decisions Adopted; UNESCO: Doha, Qatar, 2014.

12. Eriksson, B.K.; van der Heide, T.; van de Koppel, J.; Piersma, T.; van der Veer, H.W.; Olff, H. Major Changes in the Ecology of the Wadden Sea: Human Impacts, Ecosystem Engineering and Sediment Dynamics. Ecosystems 2010, 13, 752-764. [CrossRef]

13. Steinert, G.; Huelsken, T.; Gerlach, G.; Bininda-Emonds, O.R.P. Species status and population structure of mussels (Mollusca: Bivalvia: Mytilus spp.) in the Wadden Sea of Lower Saxony (Germany). Org. Divers. Evol. 2012, 12, 387-402. [CrossRef]

14. Mandema, F.S.; Tinbergen, J.M.; Ens, B.J.; Koffijberg, K.; Dijkema, K.S.; Bakker, J.P. Moderate livestock grazing of salt, and brackish marshes benefits breeding birds along the mainland coast of the Wadden Sea. Wilson J. Ornithol. 2015, 127, 467-476. [CrossRef]

15. Schmäing, T.; Grotjohann, N. Students' Word Associations with Different Terms Related to the Wadden Sea: Does the Place of Residence (Coast or Inland) Have an Influence? Educ. Sci. 2021, 11, 284. [CrossRef]

16. Großschedl, J.; Mahler, D.; Kleickmann, T.; Harms, U. Content-Related Knowledge of Biology Teachers from Secondary Schools: Structure and learning opportunities. Int. J. Sci. Educ. 2014, 36, 2335-2366. [CrossRef]

17. Mahler, D.; Großschedl, J.; Harms, U. Opportunities to Learn for Teachers' Self-Efficacy and Enthusiasm. Educ. Res. Int. 2017, 2017, 1-17. [CrossRef]

18. Mahler, D.; Großschedl, J.; Harms, U. Using doubly latent multilevel analysis to elucidate relationships between science teachers professional knowledge and students' performance. Int. J. Sci. Educ. 2017, 39, 213-237. [CrossRef]

19. Müller, N.; Elster, D. Promotion Teachers Students' System Competence by The Development of a Syndrome Approach in an Interdisciplinary Seminar. In Proceedings of the New Perspectives in Science Education: 7th Conference Edition, Florence, Italy, 22-23 March 2018; Pixel, Ed.; Libreriauniversitaria.it: Padova, Italy, 2018; pp. 284-289; ISBN 9788862929769.

20. Brauer, L.; Hößle, C. Acquiring diagnostic skills in the field of experimentation in the Wadden Sea's Teaching \& Learning Laboratory. In Challenges in Biology Education Research: [a Selection of Papers Presented at the XIth Conference of European Researchers in Didactics of Biology (ERIDOB), Karlstad, Sweden, 5-9 September 2016]; Gericke, N., Grace, M., Eds.; University Printing Office: Karlstad, Sweden, 2018; pp. 256-272; ISBN 978-91-7063-945-6.

21. Saathoff, A.; Hößle, C. Teaching \& Learning Labor Atories in Biology Teacher Education: Analysis Of Teaching Reflections. In Biology Education Research. Contemporary Topics and Directions; Puig, B., Blanco Anaya, P., Gil Quílez, M.J., Eds.; Servicio de Publicaciones Universidad de Zaragza: Zaragza, Spain, 2020; pp. 309-322. ISBN 9788416723973.

22. Weusmann, B.; Käpnick, F.; Brüning, A.-K. Lehr-Lern-Labore in der Praxis: Die Vielfaltrealisierter Konzeptionen und ihre Chancenfür die Lehramtsausbildung. In Lehr-Lern-Labore; Priemer, B., Roth, J., Eds.; Springer: Berlin/Heidelberg, Germany, 2020; pp. 27-45; ISBN 978-3-662-58912-0.

23. Wübben, A. Aus der Meeresforschung in die Nationalparkhäuser: Entwicklung, Erprobung und Implementierung neuer Umweltbildungsangebote zum Thema, Gefährdung und Schutz des UNESCO Weltnaturerbes Wattenmeer; Carl von Ossietzky Universität Oldenburg, Institut für Biologie und Umweltwissenschaften: Oldenburg, Germany, 2019.

24. Clausen, S.; Christian, A. Concept Mapping als Messverfahren für den außerschulischen Bereich: Concept Mapping for Measurement in a non scholar context. J. Didakt. Biowiss. (F) 2012, 3, 18-31.

25. Paatsch, U. Macht und Ohnmacht des Evaluators: Das Beispiel Nationalparkzentrum Wilhelmshaven „Das Wattenmeerhaus“. In (Umwelt-)Ausstellungen und Ihre Wirkung: Auf dem Weg zu Effektiven Ausstellungen; Tagung vom 29-31 Januar 1998 im Staatlichen Museum für Naturkunde und Vorgeschichte, Oldenburg; Scher, M.A., Ed.; Isensee: Oldenburg, Germany, 1998; pp. 152-171; ISBN 978-3895985522.

26. Groß, J. Die Vermittlung der Nationalparkidee-Außerschulische Umweltbildung und BNE in der Evaluation. In Naturschutz und Bildung für nachhaltige Entwicklung: Fokus: Außerschulische Lernorte; Ergebnisse des F+E-Vorhabens "Bildung für nachhaltige Entwicklung (BNE)—Positionierung des Naturschutzes"; Lucker, T., Ed.; Bundesamt für Naturschutz: Bonn-Bad Godesberg, Germany, 2009; pp. 189-222; ISBN 978-3-7843-3974-0.

27. Groß, J. Orte zum Lernen-Ein kritischer Blick auf außerschulische Lehr-/Lernprozesse. In Ausserschulische Lernorte-Positionen aus Geographie, Geschichte und Naturwissenschaften; Messmer, K., von Niederhäusern, R., Rempfler, A., Wilhelm, M., Eds.; LIT: Berlin, Germany, 2011; pp. 25-49; ISBN 9783643801081.

28. Hinrichs, N. Vermittlungsstrategien des Weltnaturerbes Wattenmeer in der Kunst. World Herit. Arts Educ. 2012, 6/7, 113-120.

29. Hinrichs, N. Künstlerische Vermittlung des UNESCO-Welterbes Wattenmeer: Malerei, Land Art, Museumskoffer, 1. Auflage; ATHENA: Oberhausen, Germany, 2016; ISBN 978-3-89896-644-3.

30. Tillmann, T.; Folkerts, M.; Frank, M.; Wunderlich, J. Konzept Einer Virtuellen Exkursion Auf Die Hallig Hooge. Mainz. Geogr. Stud. 2013, 55, 43-57.

31. Tillmann, T.; Wunderlich, J. Brauchen Wir Virtuelle Welten In Den Geowissenschaften? Evaluation Zum Potential Eines „Virtuellen Exkursionsführers Der Nordseeküste“. Mainz. Geogr. Stud. 2013, 55, $29-41$. 
32. Roskam, A.; Bliesmer, K.; Komorek, M. Phänomenologisches und analoges Lernen in Nationalparkhäusern. In Qualitätsvoller Chemie- und Physikunterricht_-Normative und Empirische Dimensionen; Jahrestagung in Regensburg, 2017; Maurer, C., Ed.; Universität Regensburg: Regensburg, Germany, 2018; pp. 636-639.

33. Bliesmer, K. Physik der Küste für Außerschulische Lernorte: Eine Didaktische Rekonstruktion; Carl von Ossietzky Universität Oldenburg: Oldenburg, Germany, 2020.

34. Wagner, B. Sachlernprozesse von Kindern in interkulturellen Begegnungssituationen. J. Int. Und Interkult. Vgl. Erzieh. 2014, 20, 3-20.

35. Schmäing, T. Das UNESCO-Weltnaturerbe Wattenmeer im Fokus von Umweltbildung und von Bildung für Nachhaltige Entwicklung: Welchen Einfluss Hat Eine Wattexkursion auf Die Umwelteinstellungen und Die Naturverbundenheit von SchülerInnen? Bielefeld, Germany, 2020.

36. Schmäing, T. Lernen im und über das UNESCO-Weltnaturerbe Wattenmeer: Die Relevanz von Kontextsensibilität und Datenvergleichbarkeit im Mixed-Methods-Design; Frankfurt am Main, Germany, 2019.

37. Phillips, A. The history of the internationalsystem of protected areamanagement categories. PARKS J. 2004, 14, 4-14.

38. Sellars, R.W. Preserving Nature in the National Parks: A History: With a New Preface and Epilogue; Yale University Press: New Haven, CT, USA, 2009; ISBN 978-0-300-15414-6.

39. IUCN. Guidelines for Applying Protected Area Management Categories Including IUCN WCPA Best Practice Guidance on Recognising Protected Areas and Assigning Management Categories and Governance Types; Dudley, N., Ed.; IUCN: Gland, Switzerland, 2013; ISBN 978-2-8317-1636-7.

40. Bergmann, H.-H.; Wille, V. Flüchten oder gewöhnen? Feindabwehrstrategien wildlebender Tiere als Reaktion auf Störsituationen. In Störungsökologie: Sammelband der Veranstaltungen: "Ökologiesymposium Störungsökologie" am 25. November 1999 in Starnberg ; "Wer Macht Unsere Wildtiere so Scheu?" am 20. und 21. September 1999 in Pullach; Sturm, P., Mallach, N., Eds.; Bayerische Akademie für Naturschutz und Landschaftspflege (ANL): Laufen, Salzach, 2001; pp. 17-21; ISBN 978-3-931175-59-7.

41. Van der Knaap, W.O.; van Leeuwen, J.F.N.; Fahse, L.; Szidat, S.; Studer, T.; Baumann, J.; Heurich, M.; Tinner, W. Vegetation and disturbance history of the Bavarian Forest National Park, Germany. Veget. Hist. Archaeobot. 2020, 29, 277-295. [CrossRef]

42. Gesetz über den Nationalpark. „Niedersächsisches Wattenmeer“: NWattNPG. 2001. Available online: http://www.nds-voris.de/ jportal/?quelle=jlink\&query=WattenmeerNatPG+ND\&psml=bsvorisprod.psml\&max=true\&aiz=true (accessed on $17 \mathrm{July} 2021$ ).

43. Nationalparkverwaltung Niedersächsisches Wattenmeer. Unser Nationalpark-Mitten im Weltnaturerbe Wattenmeer, 8th ed.; Schriftenreihe Nationalpark Niedersächsisches Wattenmeer: Wilhelmshaven, Germany, 2020.

44. Adie, B.A.; Hall, C.M. Who visits World Heritage? A comparative analysis of three cultural sites. J. Herit. Tour. 2017, 12, 67-80. [CrossRef]

45. Convention Concerning the Protection of the World Cultural and Natural Heritage. 1972. Available online: https:/ whc.unesco. org/archive/convention-en.pdf (accessed on 17 July 2021).

46. Abdulla, A.A.; Obura, D. Marine Natural Heritage and the World Heritage List: Interpretation of World Heritage Criteria in Marine Systems, Analysis of Biogeographic Representation of Sites, and a Roadmap for a Addressing Gaps; IUCN: Gland, Switzerland, 2013; ISBN 978-2-8317-1629-9.

47. Bertacchini, E.; Liuzza, C.; Meskell, L.; Saccone, D. The politicization of UNESCO World Heritage decision making. Public Choice 2016, 167, 95-129. [CrossRef]

48. Talan, A.; Tyagi, R.D.; Surampalli, R.Y. Social Dimensions of Sustainability. In Sustainability; Surampalli, R., Zhang, T., Goyal, M.K., Brar, S., Tyagi, R., Eds.; Wiley: Hoboken, NJ, USA, 2020; pp. 183-206. ISBN 9781119433965.

49. Lemke, T. Die Natur in der Soziologie. Versuch einer Positionsbestimmung. Leviathan 2007, 35, 248-255. [CrossRef]

50. Beck, U. Risikogesellschaft: Auf Dem Weg in Eine Andere Moderne; Suhrkamp, ProQuest Ebook Central: Berlin, Germany, 2016; ISBN 978-3-518-75229-6.

51. Görg, C. Natur und Gesellschaft. In Soziologische Basics; Scherr, A., Ed.; VS Verlag für Sozialwissenschaften: Wiesbaden, Germany, 2013; pp. 183-189; ISBN 978-3-531-19878-1.

52. Luhmann, N. Ecological Communication; University of Chicago Press: Chicago, IL, USA, 1989; ISBN 978-0226496511.

53. Lockie, S. What is environmental sociology? Environ. Sociol. 2015, 1, 139-142. [CrossRef]

54. Rolston, H. Nature for Real: Is Nature a Social Construct. In The Philosophy of the Environment; Chappell, S.G., Ed.; Edinburgh University Press: Edinburgh, UK, 1997; pp. 38-64; ISBN 978-0748609116.

55. Eder, K. The Social Construction of Nature: A Sociology of Ecological Enlightenment; Sage: London, UK, 1996 ; ISBN 9780803978492.

56. Evernden, N. The Social Creation of Nature; Johns Hopkins University Press: Baltimore, MD, USA, $1992 ;$ ISBN 9780801845482.

57. Demeritt, D. What is the 'social construction of nature'? A typology and sympathetic critique. Prog. Hum. Geogr. 2002, 26, 767-790. [CrossRef]

58. Elliott, M.A.; Schmutz, V. World heritage: Constructing a universal cultural order. Poetics 2012, 40, 256-277. [CrossRef]

59. Schäfer, H. „Outstanding universal value“. Die Arbeit an der Universalisierung des Wertvollen im UNESCO-Welterbe. Berl. J. Soziol. 2016, 26, 353-375. [CrossRef]

60. Su, Y.-W.; Lin, H.-L. Analysis of international tourist arrivals worldwide: The role of world heritage sites. Tour. Manag. 2014, 40, 46-58. [CrossRef]

61. Buckley, R. Tourism and Natural World Heritage: A Complicated Relationship. J. Travel Res. 2018, 57, 563-578. [CrossRef]

62. Pocock, C.; Lilley, I. Who Benefits? World Heritage and Indigenous People. Herit. Soc. 2017, 10, 171-190. [CrossRef] 
63. Rastegar, R.; Zarezadeh, Z.; Gretzel, U. World heritage and social justice: Insights from the inscription of Yazd, Iran. J. Sustain. Tour. 2021, 29, 521-540. [CrossRef]

64. Jha, S. Can Natural World Heritage Sites promote development and social harmony? Biodivers. Conserv. 2005, 14, 981-991. [CrossRef]

65. Landorf, C. Managing for sustainable tourism: A review of six cultural World Heritage Sites. J. Sustain. Tour. 2009, 17, 53-70. [CrossRef]

66. Allan, J.R.; Venter, O.; Maxwell, S.; Bertzky, B.; Jones, K.; Shi, Y.; Watson, J.E. Recent increases in human pressure and forest loss threaten many Natural World Heritage Sites. Biol. Conserv. 2017, 206, 47-55. [CrossRef]

67. Markham, A.; Osipova, E.; Lafrenz Samuels, K.; Caldas, A. World Heritage and Tourism in a Changing Climate; United Nations Environment Programme, Nairobi, Kenya and United Nations Educational, Scientific and Cultural Organization: Paris, France, 2016; ISBN 978-92-3-100152-9. Available online: https:/ / portals.iucn.org/library/sites/library/files/documents/2016-022.pdf (accessed on 17 July 2021).

68. Warren, H.C. A History of the Association Psychology; Charles Scribner's Sons: New York, NY, USA, 1921.

69. Bogner, F.X. Assoziationstests und Ökologieunterricht/Umwelterziehung am außerschulischen Lernort. Verh. Ges. Ökol. 1995, 24, $465-470$.

70. Tsai, C.-C.; Huang, C.-M. Exploring students' cognitive structures in learning science: A review of relevant methods. J. Biol. Educ. 2002, 36, 163-169. [CrossRef]

71. Maichle, U. Wissen, Verstehen und Problemlösen im Bereich der Physik.; Lang: Frankfurt am Main, Germany, 1985; ISBN 3-8204-5642-2.

72. Schaefer, G. Begriffsforschung als Mittel zur Unterrichtsgestaltung. In Sprache und Verstehen im Biologieunterricht: Bericht über die 8. Internationale Arbeitstagung der Sektion Fachdidaktik Biologie im VDBiol zum Thema "Sprache und Verstehen im Biologieunterricht" in Bad Zwischenahn vom 30.09.91 bis 04.10.91; Entrich, H., Ed.; Leuchtturm-Verl.: Alsbach/Bergstraße, Germany, 1992; pp. 128-139; ISBN 3-88064-221-4.

73. Kostova, Z. Word Association Test for Studying Conceptual Structures of Teachers and Students. Bulg. J. Sci. Educ. Policy 2008, 2, 209-231.

74. Dikmenli, M. Biology students' conceptual structures regarding global warming. Energy Educ. Sci. Technol. Part B Soc. Educ. Stud. 2010, 2, 21-38.

75. Dikmenli, M. Biology Student Teachers' Conceptual Frameworks regarding Biodiversity. Education 2010, 130, 479-489.

76. Kurt, H. Biology student teachers' cognitive structure about "Living thing”. Educ. Res. Rev. 2013, 8, 871-880.

77. Kurt, H. Determining Biology Teacher Candidates' Conceptual Structures About Energy and Attitudes Towards Energy. J. Balt. Sci. Educ. 2013, 12, 399-423.

78. Kurt, H.; Ekici, G.; Aktas, M.; Aksu, O. Determining Biology Student Teachers' Cognitive Structure on the Concept of “Diffusion" Through the Free Word-Association Test and the Drawing-Writing Technique. IES 2013, 6. [CrossRef]

79. Bogner, F.X.; Wiseman, M. Association tests and outdoor ecology education. Eur. J. Psychol. Educ. 1997, 12, 89-102. [CrossRef]

80. Dieser, O.; Bogner, F.X. Intervention Impact on Young Students' Associations about Wolf and Lynx. Soc. Anim. 2019, 27, 544-574. [CrossRef]

81. Schaefer, G. Concept Formation in Biology: The Concept 'Growth'. Eur. J. Sci. Educ. 1979, 1, 87-101. [CrossRef]

82. Duit, R. Energievorstellungen. Nat. Im Unterr. Phys. Chem. 1986, 34, 7-9.

83. Burger, J. Schülervorstellungen zu "Energie im Biologischen Kontext"-Ermittlungen, Analysen und Schlussfolgerungen: Ein Beitrag zur Verminderung von Lernschwierigkeiten im Biologieunterricht der Sekundarstufen Durch Vermehrte Berücksichtigung von Schülervorstellungen zu "Energie im Biologischen Kontext" in Konstruktivistischer Lernumgebung; Universität Bielefeld: Bielefeld, Germany, 2001.

84. Reitschert, K.; Hößle, C. Wie Schüler ethisch bewerten: Eine qualitative Untersuchung zur Strukturierung und Ausdifferenzierung von Bewertungskompetenz in bioethischen Sachverhalten bei Schülern der Sek. I. Z. Didakt. Nat. 2007, 13, 125-143.

85. Woodworth, R.; Schlosberg, H. Experimental Psychology: Revised Edition; Holt, Rinehart and Winston: New York, NY, USA, 1965.

86. Beatty, I.D.; Gerace, W.J.; Dufresne, R.J. Measuring and Modeling Physics Students' Conceptual Knowledge Structures through Term Association Times; UMass Physics Education Research Group: Amherst, MA, USA, 2007.

87. Schaefer, G. Die Wissenschaftssprache der Biologie im Lichte "inklusiven Denkens". In Kommunikative Grundlagen des Naturwissenschaftlichen Unterrichts; Schaefer, G., Loch, W., Schaefer-Loch, Eds.; Beltz: Weinheim, Germany, 1980; pp. 99-134; ISBN 3-407-69120-3.

88. Müller, W.G. Ein interkultureller Vergleich affektiver und assoziativer Wortbedeutungen. Sprache Kognit. 1998, 17, 73-88.

89. Bortz, J.; Döring, N. Forschungsmethoden und Evaluation: Für Human- und Sozialwissenschaftler, 4th ed.; Springer: Berlin, Germany, 2006; ISBN 978-3-540-33305-0.

90. Crossley, A.; Hirn, N.; Starauschek, E. Schülervorstellungen zur Energie-Eine Replikationsstudie. In Didaktik der Physik: Bochum 2009; CD Tagungsbeiträge zur Frühjahrstagung der DPG, des Fachverbandes Didaktik der Physik der Deutschen Physikalischen Gesellschaft, Bochum 2009; Beiträge zur MNU-Tagung, Regensburg 2009, Deutscher Verein zur Förderung des Mathematischen und Naturwissenschaftlichen Unterrichts, 1st ed.; Nordmeier, V., Ed.; Lehmanns Media: Berlin, Germany, 2009; ISBN 978-3-86541-371-0.

91. Hammann, M.; Jördens, J. Offene Aufgaben codieren. In Methoden in der Naturwissenschaftsdidaktischen Forschung; Krüger, D., Parchmann, I., Schecker, H., Eds.; Springer: Berlin/Heidelberg, Germany, 2014; pp. 169-178; ISBN 978-3-642-37826-3.

92. Döring, N.; Bortz, J. Forschungsmethoden und Evaluation in den Sozial- und Humanwissenschaften; 5. Vollständig Überarbeitete, Aktualisierte und Erweiterte Auflage; Springer: Berlin/Heidelberg, Germany, 2016; ISBN 978-3642410888. 
93. Sellmann, D. Umweltbildung zum Thema Klimawandel im Botanischen Garten: Wissen, Einstellungen und Konzepte von Jugendlichen; Universität Bayreuth: Bayreuth, Germany, 2011.

94. Altman, D.G. Practical Statistics for Medical Research, 1st ed.; Chapman and Hall: London, UK, 1991; ISBN 0-412-27630-5.

95. Rasch, B.; Friese, M.; Hofmann, W.; Naumann, E. Verfahren für Nominaldaten. In Quantitative Methoden 2; Rasch, B., Friese, M., Hofmann, W., Naumann, E., Eds.; Springer: Berlin/Heidelberg, Germany, 2014; pp. 111-132; ISBN 978-3-662-43547-2.

96. Diaz-Bone, R. Statistik für Soziologen, 5th ed.; Überarbeitete Auflage; UVK Verlag: München, Germany, 2019; ISBN 9783825252106.

97. Cohen, J. Statistical Power Analysis for the Behavioral Sciences, 2nd ed.; Erlbaum: Hillsdale, NJ, USA, 1988; ISBN 0-8058-0283-5.

98. Kment, E. Die Assoziationstechnik -Eindrücke zum geplanten Nationalpark Kalkalpen. In Analyse zur Raumwahrnehmung der geplanten Nationalparkregion Oberösterreichische Kalkalpen: Ablauf und Ergebnisse Eines Pilotprojektes in der Gemeinde Großraming; Weixlbaumer, N., Deimel, A., Hatz, G., Kment, E., Eds.; Amt der Oö. Landesregierung: Leonstein, Austria, 1991 ; pp. 28-36.

99. Kment, E. Der “assoziative" Nationalpark. In Akzeptanz und Raumwahrnehmungsanalyse: Zum Geplanten Nationalpark O.ö. Kalkalpen; Weixlbaumer, N., Ed.; Amt der Oö. Landesregierung: Leonstein, Austria, 1994; pp. 27-35.

100. Mose, I. Akzeptanz, Einstellung und Image als Einflussgrößen von Großschutzgebieten. Einige theoretische und methodische Vorüberlegungen. In Wahrnehmung und Akzeptanz von Großschutzgebieten; Mose, I., Ed.; BIS-Verl. der Carl-von-OssietzkyUniversität: Oldenburg, Germany, 2009; pp. 9-36; ISBN 978-3-8142-2147-2.

101. Wölfle, F.; Preisel, H.; Heinlein, V.; Türk, S.; Arnberger, A. Abschlussbericht zum Sozioökonomischen Monitoring 2014-2015: Besuchermonitoring und regionalwirtschaftliche Effekte im Nationalpark Eifel; Nationalparkverwaltung Eifel: Schleiden-Gemünd, Germany, 2016.

102. Haller, D. Aussensicht des Schweizerischen Nationalparks; ürcher Hochschule für Angewandte Wissenschaft: Zürcher Hochschule für Angewandte Wissenschaften: Zurich, Switzerland, 2008.

103. Job, H.; Fließbach-Schendzielorz, M.; Bittlingmaier, S.; Herling, A.; Woltering, M. Akzeptanz der Bayerischen Nationalparks: Ein Beitrag zum Sozioökonomischen Monitoring in den Nationalparks Bayerischer Wald und Berchtesgaden; Würzburg University Press: Würzburg, Germany, 2019; ISBN 9783958261020.

104. Nationalparkverwaltung Bayerischer Wald. Die Akzeptanz des Nationalparks bei der Lokalen Bevölkerung; Nationalparkverwaltung Bayerischer Wald: Grafenau, Germany, 2011.

105. Erdmann, C. Besucherbefragung im Nationalpark Eifel und in Seiner Angrenzenden Region: Juni bis November 2005-Kurzfassung des Endberichtes; Rheinisch-Westfälische Technische Hochschule: Aachen, Germany, 2005.

106. Quack, H.-D.; Wachowiak, H. Welterbe und Tourismus: Ausgewählte Forschungsergebnisse. In Kulturtourismus zu Beginn des 21. Jahrhunderts: Festschrift für Albrecht Steinecke; Quack, H.-D., Klemm, K., Eds.; Oldenbourg Verlag: München, Germany, 2013; pp. 279-295; ISBN 9783486715019.

107. Kremer, D.; Lehmeier, H. Tourismus im UNESCO-Welterbe Bamberg: Auswertung der Befragungen im Juni 2009; Universität Bamberg Lehrstuhl für Geographie I (Kulturgeographie): Bamberg, Germany, 2010.

108. Lohmann, D. Erdöl und Erdgas „made in Germany“. In Im Fokus: Bodenschätze; Lohmann, D., Podbregar, N., Eds.; Springer: Berlin/Heidelberg, Germany, 2012; pp. 57-71; ISBN 978-3-642-22610-6.

109. Van Beusekom, J.; Thiel, R.; Bobsien, I.; Boersma, M.; Buschbaum, C.; Dänhardt, A.; Darr, A.; Friedland, R.; Kloppmann, M.; Kröncke, I.; et al. Aquatische Ökosysteme: Nordsee, Wattenmeer, Elbeästuar und Ostsee. In Hamburger Klimabericht-Wissen über Klima, Klimawandel und Auswirkungen in Hamburg und Norddeutschland; von Storch, H., Meinke, I., Claußen, M., Eds.; Springer: Berlin/Heidelberg, Germany, 2018; pp. 89-107; ISBN 978-3-662-55378-7.

110. Siecke, M. Bilanz über 20 Jahre Nationalpark Niedersächsisches Wattenmeer; WWF Deutschland: Frankfurt am Main, Germany, 2006.

111. Beckmann, O. Die Akzeptanz des Nationalparks Niedersächsisches Wattenmeer bei der Einheimischen Bevölkerung; Lang: Frankfurt am Main, Germany, 2003; ISBN 978-3-631-50444-4.

112. Gätje, C. Sozio-Ökonomisches Monitoring (Söm Watt) in Der Nationalpark-Region: Söm-Bericht 2019; Nationalparkverwaltung Schleswig-Holsteinisches Wattenmeer: Tönning, Germany, 2019. 